\title{
Article \\ Conversion of Slaughterhouse Wastes to Solid Fuel Using Hydrothermal Carbonization
}

\author{
Jongkeun Lee ${ }^{1}{ }^{\oplus}$, Sungwan Cho ${ }^{1}$, Daegi Kim ${ }^{2} \oplus$, JunHee Ryu ${ }^{1}$, Kwanyong Lee ${ }^{3}$, Haegeun Chung ${ }^{1}$ \\ and Ki Young Park ${ }^{1, *}$ \\ 1 Department of Civil and Environmental Engineering, College of Engineering, Konkuk University, \\ Seoul 05029, Korea; leejk84@konkuk.ac.kr (J.L.); tjdhk7889@naver.com (S.C.); \\ carrot.jh@gamil.com (J.R.); hchung@konkuk.ac.kr (H.C.) \\ 2 Department of Environmental Engineering, College of Engineering, Daegu University, \\ Gyeongsan 38453, Gyeongsangbuk-do, Korea; daegi.kim81@daegu.ac.kr \\ 3 Department of Environment and Public Health, College of Health Science, Jangan University, \\ Gyeonggi 18331, Gyeonggi-do, Korea; kwanyong76@jangan.ac.kr \\ * Correspondence: kypark@konkuk.ac.kr; Tel.: +82-2-450-3736
}

Citation: Lee, J.; Cho, S.; Kim, D.; Ryu, J.; Lee, K.; Chung, H.; Park, K.Y. Conversion of Slaughterhouse Wastes to Solid Fuel Using Hydrothermal Carbonization. Energies 2021, 14 , 1768. https://doi.org/10.3390/ en14061768

Academic Editors: Sihyun Lee and Jiho Yoo

Received: 29 January 2021

Accepted: 19 March 2021

Published: 22 March 2021

Publisher's Note: MDPI stays neutral with regard to jurisdictional claims in published maps and institutional affiliations.

Copyright: (c) 2021 by the authors. Licensee MDPI, Basel, Switzerland. This article is an open access article distributed under the terms and conditions of the Creative Commons Attribution (CC BY) license (https:// creativecommons.org/licenses/by/ $4.0 /)$.

\begin{abstract}
In this study, cattle and pig slaughterhouse wastes (SHWs) were hydrothermally carbonized at $150-300{ }^{\circ} \mathrm{C}$, and the properties of SHW-derived hydrochar were evaluated for its use as a solid fuel. The results demonstrated that increasing the hydrothermal carbonization (HTC) treatment temperature improved the energy-related properties (i.e., fuel ratio, higher heating value, and coalification degree) of both the cattle and pig SHW-derived hydrochars. However, the improvements of cattle SHW-derived hydrochars were not as dramatic as that of pig SHW-derived hydrochars, due to the lipid-rich components that do not participate in the HTC reaction. In this regard, there was no merit of using HTC treatment on cattle SHW for the production of hydrochar or using the hydrochar as a solid fuel in terms of energy retention efficiency. On the other hand, a mild HTC treatment at approximately $200^{\circ} \mathrm{C}$ was deemed suitable for converting pig SHW to value-added solid fuel. The findings of this study suggest that the conversion of SHWs to hydrochar using HTC can provide an environmentally benign method for waste treatment and energy recovery from abandoned biomass. However, the efficiency of energy recovery varies depending on the chemical composition of the raw feedstock.
\end{abstract}

Keywords: hydrochar; hydrothermal carbonization; slaughterhouse waste; solid fuel

\section{Introduction}

The increase in the consumption of meat and meat products has led to the expansion of the slaughtering industry and the consequent increase in biological waste production [1] Slaughterhouse waste (SHW) is the animal product remaining after the manufacture of the principal commodity in slaughterhouses and formally consists of inedible offal and fats [2]. Most SHW is used as a raw material in the rendering industry for the production of pet and animal feed. However, outbreaks of livestock infectious diseases, such as foot-and-mouth disease, mad cow disease, and African swine fever, hinder the use of the SHW in pet and animal feed production, and even in application as fertilizers [3]. Thus, significant amounts of SHW are underutilized and are discarded via incineration or landfills. The disposal methods not only have a negative impact on the environment by generating secondary pollutants (e.g., odor and leachate), but also lead to an economic burden on the meat industry.

Recent advances in the SHW utilization pathways include its application as a source of industrial proteins, enzymes, and lipids [4,5]. Despite being an organic-rich source for industrial raw materials, SHW has process-applicable limitations and is its use is considered challenging for functional applications due to its heterogeneous composition 
(e.g., nonorganic compounds) and poor solubility [1,6]. More recently, SHW has received considerable attention as a feedstock for bioenergy production $[7,8]$, particularly due to its high organic content. Increasing environmental concerns (e.g., fossil fuel depletion, carbon emissions, and waste management) necessitate efficient methods for energy recovery and waste management.

Hydrothermal carbonization (HTC) is a thermochemical reaction-based method which occurs in a relatively low temperature range $\left(150-300^{\circ} \mathrm{C}\right)$ with moisture and autogenous pressure $[9,10]$. The relatively low energy input and mild treatment conditions of HTC have caused it to receive attention as an alternative biomass treatment technology rather than conventional thermal treatment technologies (e.g., pyrolysis, combustion) [11,12]. During the HTC reaction, various types of organic matter are converted into a valuable carbon-rich material (i.e., hydrochar). The operating conditions of the HTC (e.g., treatment temperature) affect the yield, physicochemical properties, and the functionality of hydrochar [13]. Hydrochar is a multifunctional carbonaceous material which can aid environmental remediation, soil amendment, and carbon sequestration, as well as serve as an alternative solid fuel [14]. Recently, the potential use of hydrochar as a solid fuel has received considerable attention owing to its enhanced heating value, thermal stability, and material structure, especially when compared to untreated biomass [15]. HTC boosts the energy-related properties of hydrochar, making it a sole and/or auxiliary fuel source for combustion facilities [16]. The production of hydrochar using waste biomass and its application as a solid fuel can double its profits, mitigate the environmental burden of SHW management, and help find the key to sustainable development. For the above reason, considerable studies on HTC reactions for hydrochar production and its use as a solid fuel have gained significant interest in this research area. Li et al. and Roy et al. reported on potential routes for solid fuel production using hydrochar derived from red jujube branch and peat moss, respectively [12,17]. Not only experimental research but also process efficiency modeling and cost analysis studies on HTC reactions have been published. Lucian and Fiori provide are a useful reference to evaluate the HTC process in terms of the environment and economics [18].

Herein, we focused on the conversion of cow and pig SHWs into hydrochar. The properties of the resultant hydrochars were evaluated for their use as solid fuels. We investigated the effects of the chemical feedstock composition on the hydrochar yield and properties. Finally, we determined optimal HTC treatment conditions for the tested SHWs to recover energy more efficiently.

\section{Materials and Methods}

\subsection{Feedstock}

Cattle and pig SHWs were obtained from a domestic meat processing company and were used as feedstocks for hydrochar production by HTC. The SHWs were moved to the laboratory immediately after collection, and the impurities (e.g., horn, feather, toenail) were removed. The cattle SHW used in this study was mainly composed of fat, kidney, and genitals, whereas pig SHW consisted of fat, liver, lung, and brain tissues. The components of each SHW type were ground using a cryogenic grinder (SPEX 6875D Freezer/Mill, SPEX SamplePrep, Metuchen, NJ, USA) and homogenized by blending. The sample pulverizing was conducted following manufacturer's instruction, but grinding time and rate were modified referring to our previous work. The sample ( $2 \mathrm{~g})$ was continuously cooled until $-196^{\circ} \mathrm{C}$, and the constant temperature was maintained during the entire grinding process. The grinding time was $60 \mathrm{~s}$ at a rate of 10 cycles per second. To avoid sample spoilage, the prepared SHWs were frozen $\left(<-20^{\circ} \mathrm{C}\right)$ until further use.

\subsection{Hydrothermal Carbonization (HTC)}

SHWs were hydrothermally carbonized using a batch-type laboratory-scale reactor at four different temperatures $\left(150,200,250\right.$, and $\left.300^{\circ} \mathrm{C}\right)$. The hydrothermal carbonization at each temperature was conducted in duplicate, and the products were mixed and analyzed 


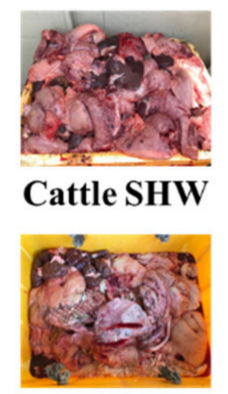

Pig SHW together. The Teflon-lined stainless-steel reactor body with a total inner volume of $1 \mathrm{~L}$ was connected to a heating control system and a steam condenser. The HTC reaction was performed for $30 \mathrm{~min}$ at the preset temperature, and the pressure of the reactor was not regulated (autogenous pressure atmosphere was maintained during the HTC reaction). For each treatment, $300 \mathrm{~mL}$ of cattle or pig SHW was loaded with the same volume of deionized water into the reactor vessel and nitrogen gas was purged for $5 \mathrm{~min}$ to create anaerobic conditions, and it was then sealed. A mechanical agitator was operated at a speed of $200 \mathrm{rpm}$, and the contents in the reactor were continuously mixed during the reaction. After the HTC reaction, the residual steam was discharged, and the inner temperature and pressure of the reactor were lowered until they reached room temperature and atmospheric pressure, respectively. Both solid and liquid products of the HTC reaction were collected and oven-dried overnight at $105^{\circ} \mathrm{C}$. Finally, the hydrochar was obtained as dry matter and analyzed. The simple layout of the experimental setup is shown in Figure 1.
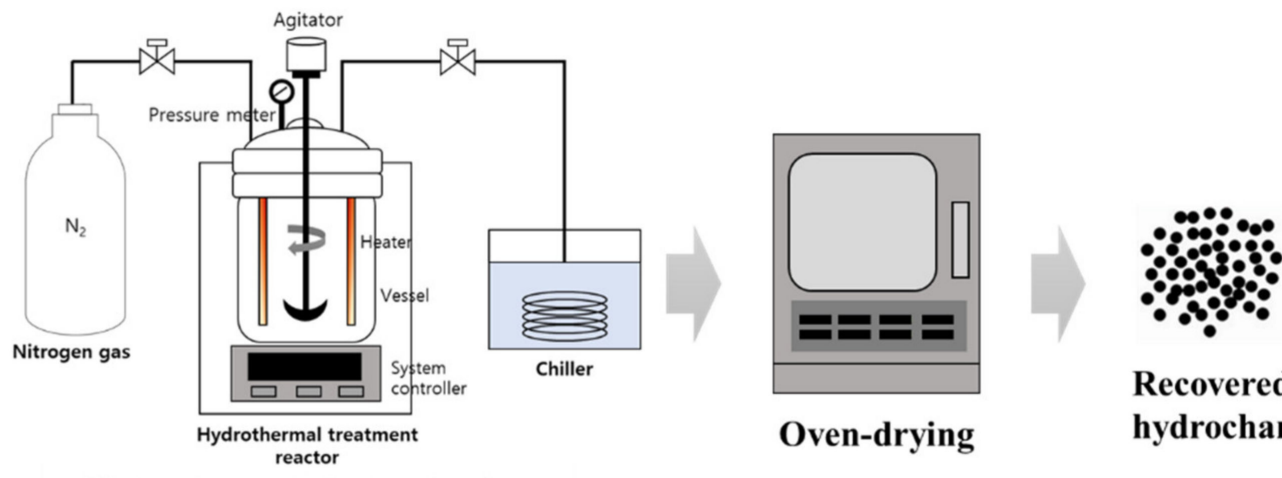

Recovered hydrochar

\section{Hydrothermal Carbonization}

Figure 1. Scheme of experimental setup.

The product yield, energy densification (ED), and energy retention efficiency (ERE) of the hydrochar were determined using Equations (1)-(3):

Product yield (dry basis) $=$ Mass of hydrochar $/$ Mass of feedstock

Energy densification = HHV of hydrochar/HHV of feedstock where HHV is the higher heating value

Energy retention efficiency $=$ Product yield $\times$ Energy densification

\subsection{Analytical Methods}

Proximate analyses of ash and volatile matter (VM) contents in the samples were conducted according to the ASTM D3174 and D3175 standard test methods, respectively. The fixed carbon (FC) content in the samples was analyzed based on the differences between the ash and VM contents. ASTM international standard test method E1758-01, AOAC international method 2001.11, and the procedure recommended by Bligh and Dyer (1959) [19] were followed to determine the total carbohydrate, protein, and lipid contents in the test samples, respectively. A high performance liquid chromatography (HPLC) system consisting of a Waters 2695 Separations Module (Waters, Milford, MA, USA) associated with a refractive index detector (Waters 2414, Waters, USA) and Sugar-Pak 1 column (Waters, USA) was employed for determination of total carbohydrate. Deionized waster was used as the mobile phase and the flow rate was $0.6 \mathrm{~mL} \mathrm{~min}-1$. The analytical grade for HPLC standard solution was used (Sigma-Aldrich).

For the instrumental analyses, the dried raw SHW and hydrochars were ground into fine particles and sieved to particle sizes of less than $250 \mu \mathrm{m}$. An elemental analyzer (Flash1112, Thermo Fisher Scientific, Bremen, Germany) was employed to perform the final analyses. The HHVs of the test samples were evaluated using a bomb calorimeter (Parr6400, 
Parr Instrument, Moline, IL, USA), followed by a standard method for calorimetric analysis (US EPA 5050). The functional group changes during the HTC reaction were analyzed using Fourier transform infrared (FTIR) spectroscopy (Vertex70, Bruker, Karlsruhe, Germany). The absorbance values of the test samples were in the range of $4000-400 \mathrm{~cm}^{-1}$.

All analyses were replicated three times for precision, and the average values of the obtained variables were used. A one-way analysis of variance (ANOVA) test using Microsoft Office Excel 2013 was conducted to evaluate a significant difference between the analysis results, where the significance level was determined at $p<0.05$.

\section{Results and Discussion}

\subsection{Properties of SHW and Hydrochar}

The raw SHWs were converted into hydrochar during the HTC reaction. The hydrochar properties at different treatment temperatures are shown in Table 1. Higher HTC temperatures led to lower VM and higher ash contents in the hydrochars due to the accelerated hydrolysis rate and dehydration of raw SHW [20]. The hydrochar ash content affects pollutant emissions and HHVs, thereby determining the suitability of the hydrochar for use as a fuel source [21]. Many countries regulate the maximum permissible level of ash content in bio-solid refuse fuel (SRF), and the domestic regulations in Korea allow a maximum ash dry weight of $15 \%$ in bio-SRF. The FC content in the hydrochar gradually increased with increasing HTC temperatures. The FC content in the cattle and pig SHWderived hydrochars increased from 0.10 to $0.55 \mathrm{wt} . \%$ (dry) and from 0.27 to $0.76 \mathrm{wt} . \%$ (dry), respectively. Higher FC content in fuels help maintain the stable state of the flame during the combustion process.

Table 1. Properties of the cattle and pig slaughterhouse wastes (SHWs) and hydrochars.

\begin{tabular}{|c|c|c|c|c|c|c|c|c|c|c|c|}
\hline & & \multicolumn{5}{|c|}{ Cattle } & \multicolumn{5}{|c|}{ Pig } \\
\hline & & Raw & 150 & 200 & 250 & 300 & Raw & 150 & 200 & 250 & 300 \\
\hline & Moisture $^{1}$ & 26.26 & - & - & - & - & 48.39 & - & - & - & - \\
\hline \multirow{3}{*}{$\begin{array}{l}\text { Proximate analysis } \\
\qquad \text { (wt.\%, dry) }\end{array}$} & VM & 98.95 & 98.61 & 98.27 & 98.09 & 98.08 & 98.69 & 98.02 & 97.78 & 97.57 & 97.11 \\
\hline & Ash & 0.95 & 1.23 & 1.34 & 1.47 & 1.37 & 1.04 & 1.36 & 1.49 & 1.68 & 2.13 \\
\hline & $\mathrm{FC}$ & 0.10 & 0.16 & 0.39 & 0.44 & 0.55 & 0.27 & 0.62 & 0.73 & 0.75 & 0.76 \\
\hline \multirow{5}{*}{$\begin{array}{l}\text { Ultimate analysis } \\
\text { (wt.\%, dry) }\end{array}$} & Carbon & 65.52 & 66.95 & 66.29 & 71.80 & 71.94 & 50.91 & 57.87 & 60.46 & 67.39 & 71.24 \\
\hline & Hydrogen & 5.63 & 5.95 & 5.32 & 5.55 & 5.40 & 6.53 & 6.81 & 5.70 & 6.07 & 5.99 \\
\hline & Oxygen & 27.81 & 26.70 & 27.61 & 22.02 & 22.01 & 40.50 & 33.48 & 32.46 & 24.58 & 21.14 \\
\hline & Nitrogen & 11.05 & 0.40 & 0.78 & 0.63 & 0.64 & 1.97 & 1.84 & 1.37 & 1.96 & 1.63 \\
\hline & Sulfur & 0.00 & 0.00 & 0.00 & 0.00 & 0.00 & 0.09 & 0.00 & 0.00 & 0.00 & 0.00 \\
\hline \multirow{3}{*}{$\begin{array}{l}\text { Composition } \\
\text { analysis } \\
\text { (wt. \%, dry) }\end{array}$} & Carbohydrate & 1.45 & 1.34 & 0.20 & 0.03 & 0.00 & 13.86 & 2.81 & 2.25 & 0.79 & 0.03 \\
\hline & Protein & 1.00 & 1.19 & 1.00 & 0.63 & 0.40 & 13.13 & 11.25 & 8.83 & 9.63 & 7.29 \\
\hline & Lipid & 74.75 & 75.66 & 82.33 & 85.05 & 85.32 & 33.25 & 50.72 & 69.32 & 85.06 & 89.17 \\
\hline
\end{tabular}

${ }^{1}$ Moisture content is based on wet weight (wt.\%, wet).

The elemental composition of the obtained hydrochar is presented in Table 1. A gradual increase in carbon content was observed in both the cattle and pig SHW-derived hydrochars with an increase in the HTC temperature. The carbon content is known to be closely associated with energy capacity of combustible material [22,23]. The carbon contents in the cattle and pig SHW-derived hydrochars increased from 65.52 to $71.94 \mathrm{wt} . \%$ (dry) and from 50.91 to $71.24 \mathrm{wt} . \%$ (dry), respectively. Meanwhile, a drastic decline in nitrogen content in the cattle SHW-derived hydrochar was observed with increasing HTC temperatures. The observation was attributed to the devolatilization of volatile nitrogen in the raw cattle SHW and the elimination of devolatilized nitrogen into the gas or liquid phase $[24,25]$. The deterioration of nitrogen content in feedstock during HTC can lower NOx emissions during the combustion process if the hydrochar is used as a solid fuel. 
Furthermore, negligible sulfur levels in both the cattle and pig SHWs revealed the potential use of the hydrochar as a clean energy source without any risk of SOx emissions.

Generally, the variable components in the feedstock undergo complex reactions during HTC and affect the hydrochar combustion characteristics [26]. The three main feedstock components (i.e., carbohydrates, proteins, and lipids) are associated with prominent changes in the physicochemical properties of hydrochar [27]. In the cattle SHW, ultrahigh lipid content was observed (74.75 wt.\%, dry), whereas carbohydrates and proteins constituted only 1.45 and $1.00 \mathrm{wt} . \%$ (dry), respectively. However, these components were distributed more evenly in the pig SHW (the content of carbohydrates, proteins, and lipids equaled 13.86, 13.13, and 33.25 wt.\% (dry), respectively). During HTC, carbohydrates tend to contribute to the formation of hydrochar, while proteins help develop $\mathrm{N}$-heterocyclic functional groups; lipids do not participate in the formation of carbonization products [26]. Therefore, each component in the raw SHW can cause changes in the energy-related properties and functional groups of the SHW-derived hydrochar. This issue is addressed in more detail in the following sections.

\subsection{Improvements in the SHW Properties}

Figure 2 presents the fuel ratios (FC/VM) and HHVs of the SHWs and hydrochars. With an increase in the HTC temperature, the fuel ratios of both the cattle and pig SHWs gradually increased. However, there was no significant increase in the fuel ratio of the pig SHW above $200^{\circ} \mathrm{C}$. The higher the fuel ratio, the better the produced solid fuel. Because the FC and VM contents in a combustible material are correlated with the combustion atmosphere by flame violence and heat flow balance, the fuel ratio is essential for determining fuel source potential [16]. Furthermore, the HHVs of the SHW-derived hydrochars were investigated to evaluate the energy potential of the hydrochars. As the HTC treatment temperature increased, all SHW-derived hydrochars had enhanced HHVs. The HHV of the pig SHW-derived hydrochar markedly increased from 4674 to $8804 \mathrm{kcal} \mathrm{kg}^{-1}$, while the equivalent value of the cattle SHW-derived hydrochar increased only by $\sim 1600 \mathrm{kcal} \mathrm{kg}^{-1}$ under the same HTC conditions. This is attributed to the aforementioned differences in the chemical compositions of the cattle and pig SHWs. Although higher lipid content in the cattle SHW led to the higher initial HHV of the raw feedstock, the increase was not dramatic because the lipids were nonreactive during the HTC reaction. Even so, the hydrolyzed lipids were probably adsorbed onto the hydrochar surface [26], and the highest HHV of the cattle SHW-derived hydrochar was comparable to that of the pig SHW-derived hydrochar.

The lower $\mathrm{H} / \mathrm{C}$ and $\mathrm{O} / \mathrm{C}$ ratios represent a greater coalification degree and advanced energy potential [13]. Both the cattle and pig SHWs underwent a combination of complex chemical reactions, especially dehydration and decarboxylation, during HTC. The coalification degree of the SHW-derived hydrochars gradually increased with an increase in the HTC temperature. Thus, it can be concluded that the economic value of raw SHWs for solid fuel use is improved by eliminating oxygen and hydrogen and proportionally increasing the carbon content in the product. In this study, the raw SHWs followed the trend of biomass coalification. However, due to the lipid-rich characteristics of the raw SHW, the SHW-derived hydrochars are positioned differently to the biomass-derived coals (i.e., in the upper left corner of Figure 3). 


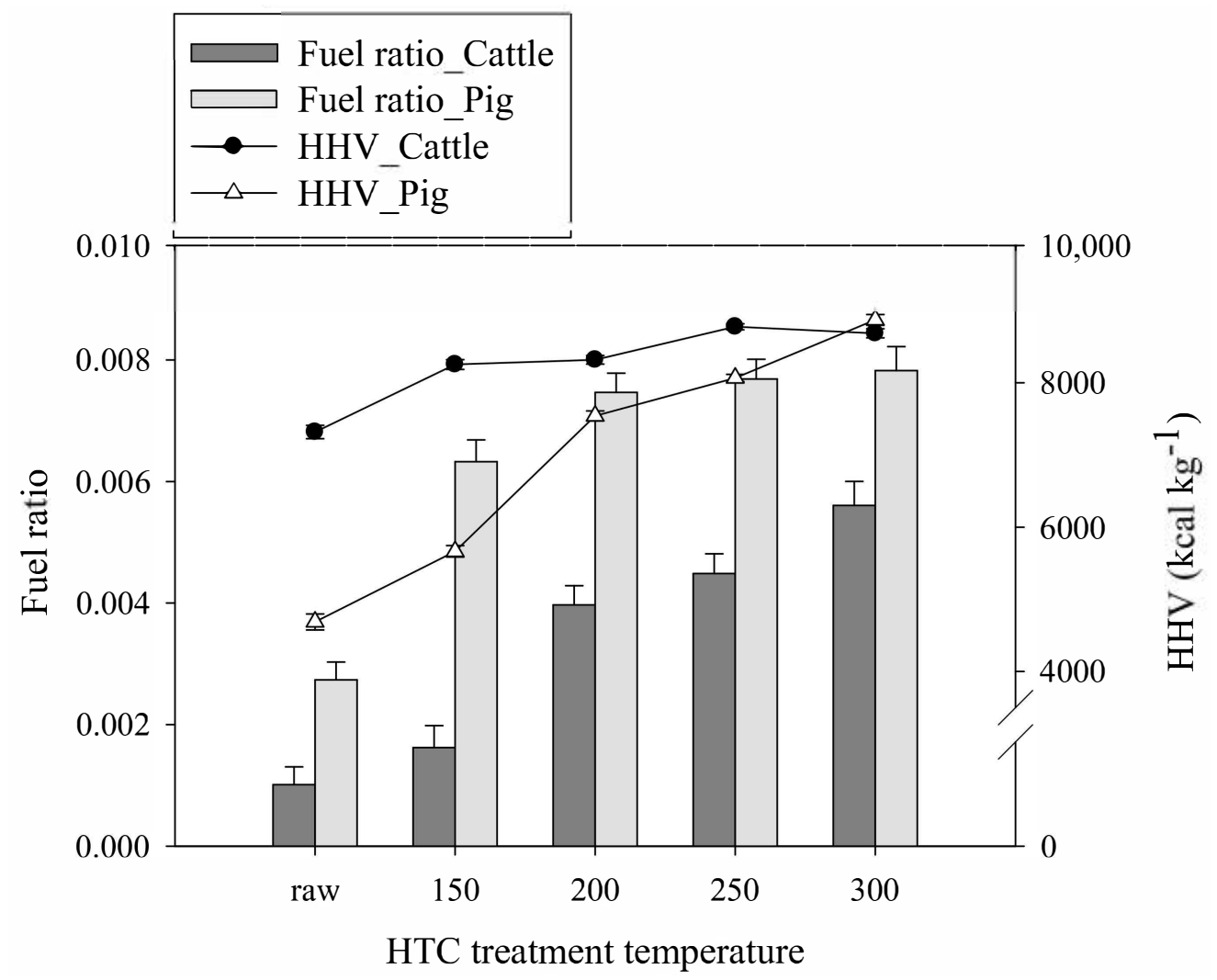

Figure 2. Fuel ratio and HHVs of the cattle and pig SHWs and hydrochars.

The shift in the coalification degree during HTC was evaluated using the van Krevelen diagram, which compares the aromaticity (atomic $\mathrm{H} / \mathrm{C}$ ratio) and the polarity (atomic $\mathrm{O} / \mathrm{C}$ ratio) of the samples (Figure 3).

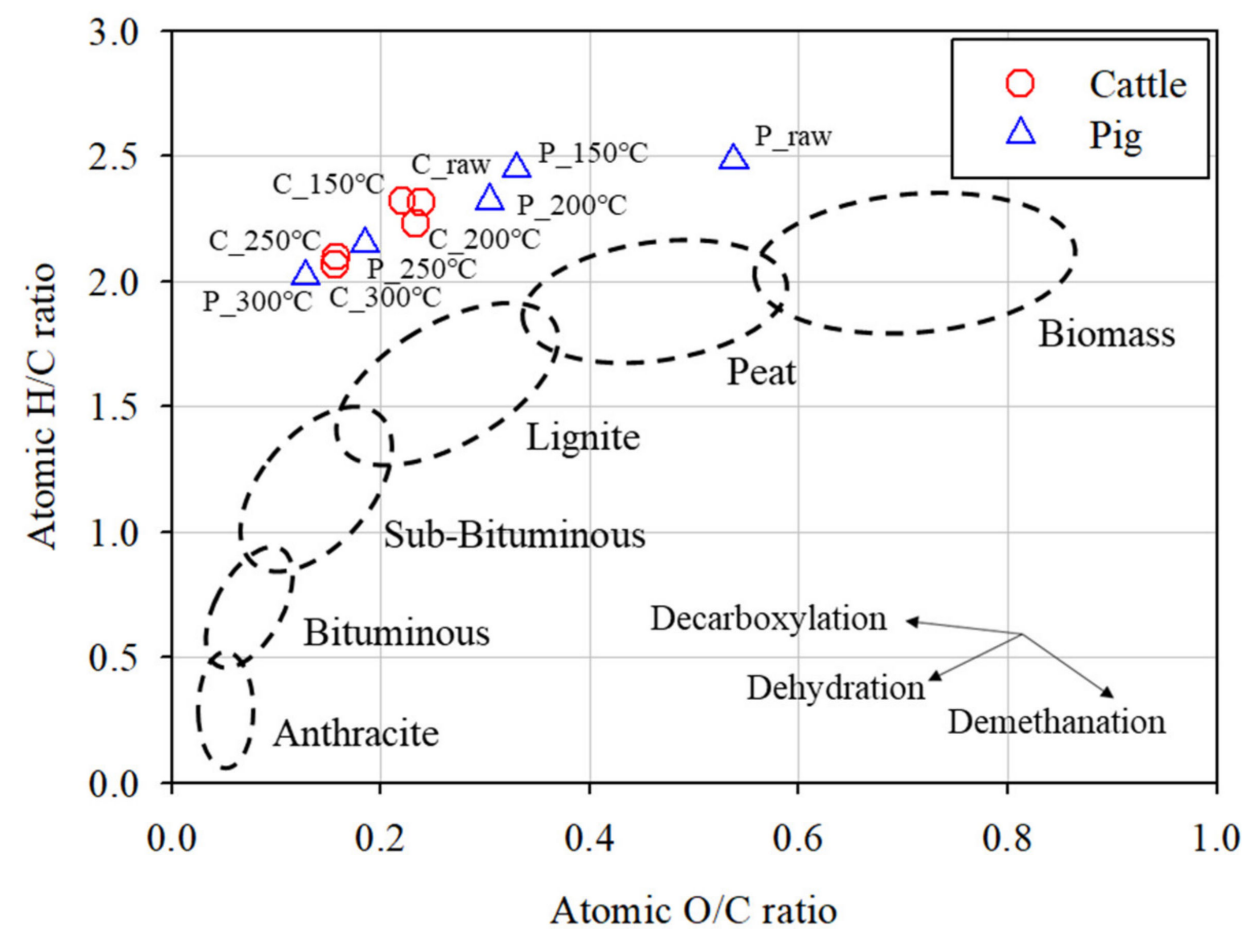

Figure 3. Van Krevelen diagram of the cattle and pig SHWs and hydrochars. 
Figure 4 shows the energy-related properties (i.e., energy retention efficiency, energy densification, and product yield) of the cattle and pig SHW-derived hydrochars. The ED of the SHW-derived hydrochars increased with an increase in the HTC temperature, and the ED value was improved to the raw SHW feedstocks (the ED of the raw SHW equaled 1.0). Owing to the aforementioned effects of chemical composition on hydrochar formation, a more substantial increase in ED was observed with the pig SHW-derived hydrochars. Meanwhile, the product yields of both the cattle and pig SHW-derived hydrochars was lowered by the continuous loss of VM and organic matter with the augmented severity in the HTC reaction. The product yield did not decline significantly, and ERE showed a similar trend to ED. When considering ERE and energy consumption at higher HTC temperatures, HTC for cattle SHW is not recommended, whereas a mild HTC temperature of $\sim 20{ }^{\circ} \mathrm{C}$ is optimal for converting pig SHW into value-added solid fuel.

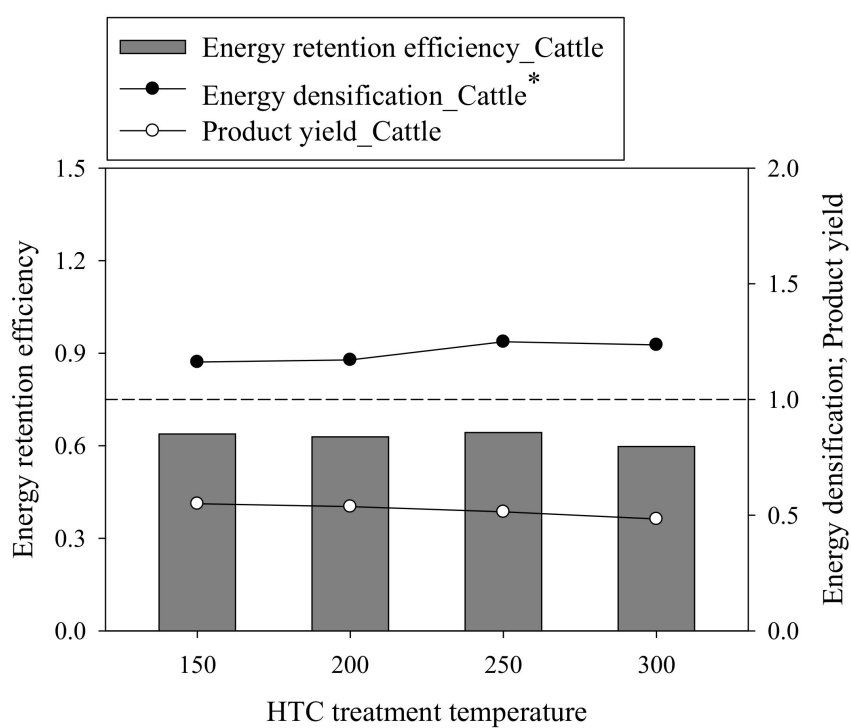

(a)

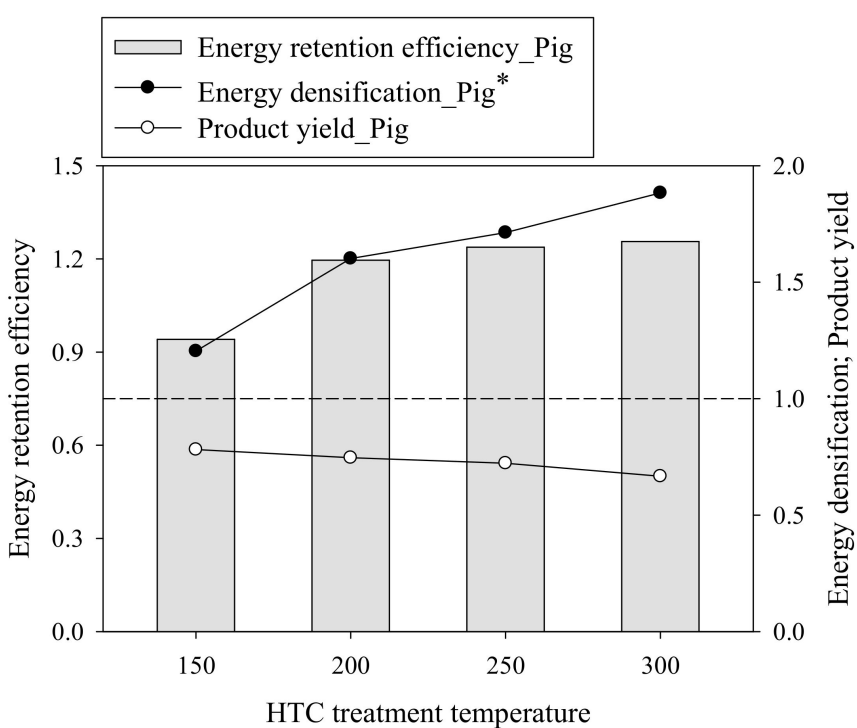

(b)

Figure 4. Energy-related properties of the SHW-derived hydrochars for (a) cattle and (b) pig. * Energy densification of the raw SHW without hydrothermal carbonization $(\mathrm{HTC})=1.0$.

\subsection{Changes of Functional Groups during the HTC Treatment}

The changes of functional groups on the SHW and hydrochar surfaces were analyzed using FTIR spectra analysis (Figure 5). Some noticeable peaks were determined based on different peak intensities at various HTC treatment temperatures. The peak at $3000-2800 \mathrm{~cm}^{-1}$ is associated with the aliphatic $\mathrm{C}-\mathrm{H}$ structure of hydrochars [28]. It represents the miscibility between lipids and water that increases when hydrogen bonding between water molecules weakens during HTC [29]. The lipid solubility in both the cattle and pig SHWs increased after HTC, and the lipid content in the raw feedstock probably became completely miscible under the supercritical conditions. The dissolved lipids were then adsorbed onto the hydrochar surface or ejected with steam after the HTC reaction. Thus, the relative peak intensity slightly decreased. The peak observed at $1650 \mathrm{~cm}^{-1}$ is related to the $\mathrm{C}=\mathrm{O}$ bond of the carboxylic group [30], indicating that decarboxylation occurred in both SHW-derived hydrochars during the hydrothermal reaction. The reaction was more intense at higher HTC temperatures. The observation of the corresponding peak in hydrochars confirmed the results of the van Krevelen diagram and the $\mathrm{H} / \mathrm{C}$ and $\mathrm{O} / \mathrm{C}$ ratios obtained herein. The changes in peak intensity at $1130 \mathrm{~cm}^{-1}$ with respect to the $\mathrm{C}-\mathrm{O}$ bond represent the carbohydrate component in the SHW [31]. The peak collapse is observed between HTC temperatures of 200 and $250{ }^{\circ} \mathrm{C}$, revealing the thermal degradation of carbohydrates [32]. In summary, the FTIR spectra analysis demonstrated that the studied SHWs were well 
carbonized and converted into hydrochar after HTC. The differences in the hydrochar functional groups were attributed to the inherent properties of the cattle and pig SHWs.

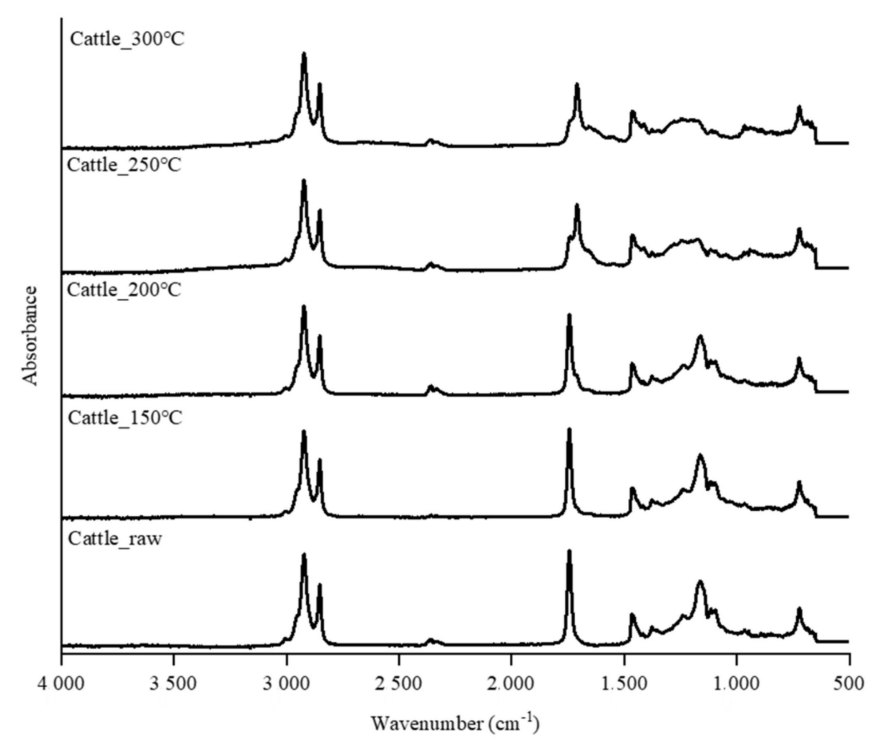

(a)

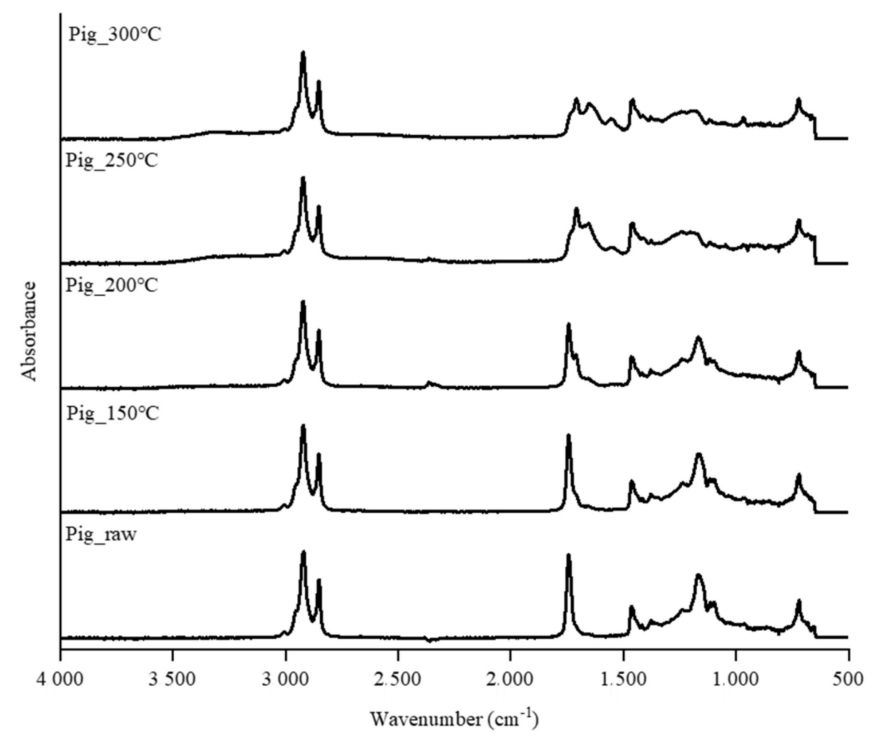

(b)

Figure 5. Fourier transform infrared (FTIR) spectra of the raw SHWs and hydrochars for (a) cattle and (b) pig.

\section{Conclusions}

This study focused on the hydrothermal treatment of cattle and pig SHWs and the potential use of SHW-derived hydrochars as a solid fuel to reduce the environmental and economic burden on the meat industry. Both the cattle and pig SHW-derived hydrochars demonstrated enhanced energy-related properties. However, the cattle SHW treated with HTC was not effective in terms of energy retention due to the lipid-rich characteristics of raw cattle SHW. A relatively low HTC treatment temperature (approximately $200{ }^{\circ} \mathrm{C}$ ) was found to be suitable for pig SHW. Thus, the HTC of cattle and pig SHWs may prove effective for waste management and the production of solid fuel. The HTC treatment efficiency should be considered as it changes based on the chemical composition of the raw feedstock.

Author Contributions: Conceptualization, J.L., S.C., J.R. and K.Y.P.; methodology, J.L., D.K. and K.L.; formal analysis, S.C. and K.L.; investigation, J.L. and D.K.; data curation, J.L., D.K., J.R. and K.Y.P.; writing-original draft preparation, J.L.; writing—review and editing, J.L. and H.C.; supervision, K.Y.P. All authors have read and agreed to the published version of the manuscript.

Funding: This work was supported by the Korea Environmental Industry \& Technology Institute through the Public Technology Program based on Environmental Policy Program, funded by Korea Ministry of Environment (MOE) (2018000710002). This work was supported by SP Bio (Pyung Kang BIM Co., Ltd.).

Institutional Review Board Statement: Not Applicable.

Informed Consent Statement: Not Applicable.

Data Availability Statement: Not Applicable.

Conflicts of Interest: The authors declare no conflict of interest. 


\section{References}

1. Adhikari, B.B.; Chae, M.; Bressler, D.C. Utilization of slaughterhouse waste in value-added applications: Recent advances in the development of wood adhesives. Polymers 2018, 10, 176. [CrossRef] [PubMed]

2. Meeker, D.L. North American Rendering: Processing high quality protein and fats for feed. Rev. Bras. Zootec. 2009, 38, 432-440. [CrossRef]

3. Gwyther, C.L.; Williams, A.P.; Golyshin, P.N.; Edwards-Jones, G.; Jones, D.L. The environmental and biosecurity characteristics of livestock carcass disposal methods: A review. Waste Manag. 2011, 31,767-778. [CrossRef]

4. Lasekan, A.; Bakar, F.A.; Hashim, D. Potential of chicken by-products as sources of useful biological resources. Waste Manag. 2013, 33, 552-565. [CrossRef] [PubMed]

5. Bah, C.S.; Bekhit, A.E.D.A.; Carne, A.; McConnell, M.A. Slaughterhouse blood: An emerging source of bioactive compounds. Compr. Rev. Food Sci. Food Saf. 2013, 12, 314-331. [CrossRef]

6. Mekonnen, T.H.; Mussone, P.G.; Stashko, N.; Choi, P.Y.; Bressler, D.C. Recovery and characterization of proteinacious material recovered from thermal and alkaline hydrolyzed specified risk materials. Process Biochem. 2013, 48, 885-892. [CrossRef]

7. Palatsi, J.; Viñas, M.; Guivernau, M.; Fernandez, B.; Flotats, X. Anaerobic digestion of slaughterhouse waste: Main process limitations and microbial community interactions. Bioresour. Technol. 2011, 102, 2219-2227. [CrossRef]

8. Franke-Whittle, I.H.; Insam, H. Treatment alternatives of slaughterhouse wastes, and their effect on the inactivation of different pathogens: A review. Crit. Rev. Microbiol. 2013, 39, 139-151. [CrossRef]

9. Broch, A.; Jena, U.; Hoekman, S.K.; Langford, J. Analysis of solid and aqueous phase products from hydrothermal carbonization of whole and lipid-extracted algae. Energies 2013, 7, 62-79. [CrossRef]

10. Lee, J.; Choi, O.K.; Oh, D.; Lee, K.; Park, K.Y.; Kim, D. Stimulation of Lipid Extraction Efficiency from Sewage Sludge for Biodiesel Production through Hydrothermal Pretreatment. Energies 2020, 13, 6392. [CrossRef]

11. Holubčík, M.; Klačková, I.; Ďurčanský, P. Pyrolysis conversion of polymer wastes to noble fuels in conditions of the Slovak Republic. Energies 2020, 13, 4849. [CrossRef]

12. Li, Z.; Yi, W.; Li, Z.; Tian, C.; Fu, P.; Zhang, Y.; Zhou, L.; Teng, J. Preparation of Solid Fuel Hydrochar over Hydrothermal Carbonization of Red Jujube Branch. Energies 2020, 13, 480. [CrossRef]

13. Lee, J.; Lee, K.; Sohn, D.; Kim, Y.M.; Park, K.Y. Hydrothermal carbonization of lipid extracted algae for hydrochar production and feasibility of using hydrochar as a solid fuel. Energy 2018, 153, 913-920. [CrossRef]

14. Lee, J.; Sohn, D.; Lee, K.; Park, K.Y. Solid fuel production through hydrothermal carbonization of sewage sludge and microalgae Chlorella sp. from wastewater treatment plant. Chemosphere 2019, 230, 157-163. [CrossRef]

15. Lee, J.; Park, K.Y. Conversion of heavy metal-containing biowaste from phytoremediation site to value-added solid fuel through hydrothermal carbonization. Environ. Pollut. 2020, 269, 116127. [CrossRef]

16. Lee, J.; Hong, J.; Jang, D.; Park, K.Y. Hydrothermal carbonization of waste from leather processing and feasibility of produced hydrochar as an alternative solid fuel. J. Environ. Manag. 2019, 247, 115-120. [CrossRef] [PubMed]

17. Roy, P.; Dutta, A.; Gallant, J. Hydrothermal carbonization of peat moss and herbaceous biomass (Miscanthus): A potential route for bioenergy. Energies 2018, 11, 2794. [CrossRef]

18. Lucian, M.; Fiori, L. Hydrothermal carbonization of waste biomass: Process design, modeling, energy efficiency and cost analysis. Energies 2017, 10, 211. [CrossRef]

19. Bligh, E.G.; Dyer, W.J. A rapid method of total lipid extraction and purification. Can. J. Biochem. Physiol. 1959, 37, 911-917. [CrossRef]

20. Liu, H.; Chen, Y.; Yang, H.; Gentili, F.G.; Söderlind, U.; Wang, X.; Zhang, W.; Chen, H. Hydrothermal carbonization of natural microalgae containing a high ash content. Fuel 2019, 249, 441-448. [CrossRef]

21. Parshetti, G.K.; Liu, Z.; Jain, A.; Srinivasan, M.; Balasubramanian, R. Hydrothermal carbonization of sewage sludge for energy production with coal. Fuel 2013, 111, 201-210. [CrossRef]

22. Sheng, C.; Azevedo, J. Estimating the higher heating value of biomass fuels from basic analysis data. Biomass Bioenergy 2005, 28, 499-507. [CrossRef]

23. Thipkhunthod, P.; Meeyoo, V.; Rangsunvigit, P.; Kitiyanan, B.; Siemanond, K.; Rirksomboon, T. Predicting the heating value of sewage sludges in Thailand from proximate and ultimate analyses. Fuel 2005, 84, 849-857. [CrossRef]

24. Rubiera, F.; Arenillas, A.; Pevida, C.; Garcia, R.; Pis, J.; Steel, K.; Patrick, J. Coal structure and reactivity changes induced by chemical demineralisation. Fuel Process Technol. 2002, 79, 273-279. [CrossRef]

25. Zhao, P.; Ge, S.; Chen, Z.; Li, X. Study on pore characteristics of flocs and sludge dewaterability based on fractal methods (pore characteristics of flocs and sludge dewatering). Appl. Therm. Eng. 2013, 58, 217-223. [CrossRef]

26. Li, Y.; Liu, H.; Xiao, K.; Jin, M.; Xiao, H.; Yao, H. Combustion and Pyrolysis Characteristics of Hydrochar Prepared by Hydrothermal Carbonization of Typical Food Waste: Influence of Carbohydrates, Proteins, and Lipids. Energy Fuels 2019, 34, 430-439. [CrossRef]

27. Li, Y.; Liu, H.; Xiao, K.; Liu, X.; Hu, H.; Li, X.; Yao, H. Correlations between the physicochemical properties of hydrochar and specific components of waste lettuce: Influence of moisture, carbohydrates, proteins and lipids. Bioresour. Technol. 2019, 272, 482-488. [CrossRef] [PubMed] 
28. De Oliveira Silva, J.; Rodrigues Filho, G.; da Silva Meireles, C.; Ribeiro, S.D.; Vieira, J.G.; da Silva, C.V.; Cerqueira, D.A. Thermal analysis and FTIR studies of sewage sludge produced in treatment plants. The case of sludge in the city of Uberlândia-MG, Brazil. Thermochim. Acta 2012, 528, 72-75. [CrossRef]

29. Peterson, A.A.; Vogel, F.; Lachance, R.P.; Fröling, M.; Antal, M.J., Jr.; Tester, J.W. Thermochemical biofuel production in hydrothermal media: A review of sub-and supercritical water technologies. Energy Environ. Sci. 2008, 1, 32-65. [CrossRef]

30. Li, M.; Li, W.; Liu, S. Hydrothermal synthesis, characterization, and $\mathrm{KOH}$ activation of carbon spheres from glucose. Carbohydr. Res. 2011, 346, 999-1004. [CrossRef]

31. Román, S.; Nabais, J.; Laginhas, C.; Ledesma, B.; González, J. Hydrothermal carbonization as an effective way of densifying the energy content of biomass. Fuel Process. Technol. 2012, 103, 78-83. [CrossRef]

32. Wei, X.; Ma, X.; Peng, X.; Yao, Z.; Yang, F.; Dai, M. Comparative investigation between co-pyrolysis characteristics of protein and carbohydrate by TG-FTIR and Py-GC/MS. J. Anal. Appl. Pyrolysis 2018, 135, 209-218. [CrossRef] 